\title{
Nesting beside old nests, but not over water, increases current nest survival in a tropical mangrove-dwelling warbler
}

\author{
Richard A. Noske • Yeni A. Mulyani • \\ Penn Lloyd
}

Received: 11 July 2012/Revised: 25 November 2012/Accepted: 29 November 2012/Published online: 30 January 2013

(C) The Author(s) 2013. This article is published with open access at Springerlink.com

\begin{abstract}
Nest predation rates often depend on how well a nest is concealed. Many tropical birds build their nests over water and/or build large pendant nests that closely resemble clumps of vegetation or flood debris, behaviours that are universally assumed to reduce nest predation rates by deterring or confusing nest predators, respectively. Yet this hypothesis has never been tested. In tropical Australian mangroves, Large-billed Gerygones Gerygone magnirostris typically build their pensile nests over tidal channels and often next to their old nests. We monitored the fate of nests of 28 pairs and used generalized linear models to investigate the importance of nest location to nesting success. Nest failure due to tidal flooding, but not predation, decreased significantly with nest height and distance from the tidal channel, suggesting that nesting over water does not always reduce nest predation, and, indeed, may incur costs through flooding. However, nest predation was significantly more likely at nests that were distant from old nests than those built close to old nests. Nest predators might give up searching for eggs or nestlings if nearby nests are empty (potential-prey-site hypothesis). Alternatively, gerygones may build near old intact nests because
\end{abstract}

Communicated by J. Fjeldså.

R. A. Noske $(\bowtie) \cdot$ Y. A. Mulyani

School of Environmental and Life Sciences,

Charles Darwin University, Darwin, NT 0909, Australia

e-mail: rnoske@tpg.com.au

P. Lloyd

Biodiversity Assessment and Management, Cleveland,

QLD 4163, Australia they signify 'safe' locations that have escaped nest predation in the past.

Keywords Nest location · Predation · Flooding ·

Large-billed Gerygones

\section{Zusammenfassung}

Nisten neben alten Nestern aber nicht über Wasser erhöht den Nesterfolg eines tropischen, Mangroven bewohnenden Singvogels

Nestprädationsraten hängen häufig davon $a b$, wie gut versteckt das Nest angelegt wird. Viele tropische Vogelarten bauen ihre Nester über Wasser und/oder bauen große, hängende Nester, welche in ihrem Erscheinen Bündeln aus Vegetation oder Getreibsel sehr ähneln. Es wird allgemein angenommen, dass dieses Verhalten die Nestprädation verringert, indem Prädatoren entweder abgehalten oder irritiert werden. Diese Hypothese wurde bisher jedoch nicht getestet. In Mangrovenwäldern des tropischen Australiens baut die Sumpfgerygone Gerygone magnirostris ihr hängendes Nest typischerweise über Gezeitenkanälen und häufig in nächster Nähe zu älteren Nestern. Es wurde der Brutverlauf an den Nestern von 28 Brutpaaren untersucht und mit Hilfe linearer Modelle der Einfluss des Nistplatzes auf den Erfolg der Brut analysiert. Es zeigte sich eine signifikant geringere Ausfallrate durch Überflutung, nicht aber durch Prädation, je höher das Nest in der Vegetation angelegt wurde und mit zunehmender Distanz des Neststandorts zum Gezeitenkanal. Daher wird angenommen, dass die Nestanlage über Wasser nicht generell zu geringerer Prädation führt und höhere Risiken durch Überflutung mit sich bringt. Die Wahrscheinlichkeit der 
Nestprädation war jedoch signifikant höher bei Nestern, die in größerer Entfernung zu älteren Nestern angelegt waren. Nestprädatoren könnten die Suche nach Gelegen aufgeben, wenn nahe gelegene Nester leer sind (,potential-prey-site hypothesis“). Ein alternativer Erklärungsansatz wäre, dass die Vögel in der Nähe alter, intakter Nester bauen, weil diese „sichere“Neststandorte ohne vorangegangene Prädationsereignisse andeuten.

\section{Introduction}

Nest predation is the major cause of reproductive failure among birds (Lack 1968; Martin 1992; Ricklefs 1969), and appears to have played a key role in shaping avian reproductive strategies, and hence life history (Fontaine and Martin 2006; Martin 1995; Weidinger 2002). Variation in the location and form of nests has been widely attributed to avoidance of nest predation (Collias and Collias 1984). Nests may be designed to conceal their contents (e.g., enclosed and domed nests) or deceive predators (e.g., camouflaged and "false" nests), or may be placed in inaccessible (e.g., cliffs) or well-guarded places (e.g., near nests of predacious birds or injurious insects) (Collias and Collias 1984). Hole-nesters, especially those that excavate their own nests, suffer less nest predation than those that build exposed nests (Martin 1995; Martin and Li 1992; Oniki 1979; Skutch 1966; von Haartman 1957; Wesolowski and Tomialojć 2005). Although well-concealed nest sites might be expected to be safer from nest predators, the relationship between nest concealment and nest survival is confounded by variation in predator faunas and strategies and parental nest defense behaviour, among other factors (Burhans and Thompson 1998; Colombelli-Négrel and Kleindorfer 2009; Götmark et al. 1995; Holway 1991; Howlett and Stutchbury 1996; Martin and Roper 1988; Nalwanga et al. 2004; Remeš 2005; Weidinger 2002). However, nest site characteristics other than height and degree of concealment by vegetation are rarely considered in studies of nest predation.

Many tropical bird species from diverse families (e.g., Tyrannidae, Eurylaimidae, Ploceidae) are known to build their nests over water (Bruce 2003; Collias and Collias 1984; Fitzpatrick 2004). Although it is universally accepted that this behaviour has evolved to hamper access to the nest by nest predators (e.g., Collias and Collias 1984; Hudgens 1997; Immelmann 1961), and tacitly assumed that such predators are either unable to swim or at least reluctant to enter water, this hypothesis has, to our knowledge, never been tested. We propose the name 'aqua-phobic nest predator' for this hypothesis. Yet nesting over water may incur fitness costs to the owners if such nests become more vulnerable to flooding by rainwater runoff or high tides (Franklin and Noske 2000; Hudgens 1997; MacGillivray 1918). Likewise, many tropical species build large pendant nests that closely resemble clumps of vegetation or flotsam (Bruce 2003; Collias and Collias 1984; Fitzpatrick 2004), and whilst this resemblance may be viewed as a form of camouflage, such nests, particularly when hanging in open spaces, are conspicuous to humans and presumably also to visually-oriented nest predators and brood parasites (Biancucci and Martin 2010).

Australasian warblers (family Acanthizidae) of the genus Gerygone are small (6-7 g) insectivorous birds whose nests are typically neat, pendant, oval or domeshaped structures composed of strips of bark, dry grass, dead leaves and vines, and featuring a hooded side entrance near the top and a small "tail" piece that hangs from the bottom of the nest. The nest of the tropical Large-billed Gerygone Gerygone magnirostris, on the other hand, is a large and untidy construction, up to $120 \mathrm{~cm}$ in length, but averaging around $50 \mathrm{~cm}$ long, with the entrance to the nest chamber in the middle portion, and liberally decorated with dead leaves and other plant materials (Higgins and Peter 2002). These nests are usually suspended conspicuously from the tips of foliage of trees overhanging rivers in mangals (mangrove communities) or rainforests, where their resemblance to tidal or flood debris has earned the species the name of "flood bird" (Beruldsen 1980; Campbell and Barnard 1917; Le Souëf 1903; Marshall 1933; McGill 1970). This resemblance is tacitly presumed to reduce predation rates by confusing visually-orientated nest predators that are unable to distinguish between nests and flotsam. The potential-prey-site hypothesis (Martin 1993; Martin and Roper 1988) proposes that the probability of a predator finding stationary prey (such as eggs or nestlings) should decrease with increasing numbers of unoccupied potential sites that must be searched, causing the predator to give up before finding the occupied site. This hypothesis has received recent empirical support (Chalfoun and Martin 2009).

As is the case with several other gerygone species, the Large-billed Gerygone often builds its nest close to nests of aggressive colonial wasps (Cornwall 1910; Johnstone 1990; MacGillivray 1914; Marshall 1933), an association which may reduce nest predation rates by intimidating potential nest predators (Collias and Collias 1984; Joyce 1993; Wunderle and Pollock 1985). In addition, active nests of this species are sometimes found within $2 \mathrm{~m}$ of abandoned or old nests, presumably built by the same pair (Higgins and Peter 2002), creating a loose cluster of two to four nests (Mulyani 2004, unpublished data; Noske, unpublished data). Such disused nests, often with blocked entrances, may act as decoys that confuse predators (Collias and Collias 1984; Whitney et al. 1996). 
In this paper, we examine the relationship between nest success and nest site characteristics of Large-billed Gerygones in mangals around Darwin, Northern Territory, Australia. Artificial nest studies in this region indicated that nest predation rates are significantly higher in mangals than in other local habitats (Noske et al. 2008), and that within mangals, rates are higher in the tall mangrove forest along tidal creeks, which are regularly flooded at high tides, than in the short mangroves surrounding bare, infrequently inundated saltflats (Mulyani 2004; Sato et al. 2010).

We predicted that (1) nests suspended directly over regularly flooded tidal channels should suffer less nest predation than those further away because non-flying nest predators should avoid the risk of falling into the water (aqua-phobic nest predator hypothesis); and (2) active nests in close proximity to old nests should suffer less predation than solitary nests, because some predators might give up searching if nearby nests are empty (potential-prey-site hypothesis). We also predicted that low nests would be flooded by very high tides, as have been observed in the study species elsewhere (MacGillivray 1918), and in an unrelated species in the study area (Franklin and Noske 2000).

\section{Methods}

Two study sites were selected within mangals around Darwin, Northern Territory, in northern Australia $\left(12^{\circ} 20^{\prime}-12^{\circ} 28^{\prime} \mathrm{S}\right.$, $130^{\circ} 48^{\prime}-130^{\circ} 55^{\prime} \mathrm{E}$; mean annual rainfall, $1,600 \mathrm{~mm}$ ), where the climate is monsoon-tropical, with relatively uniform temperatures year-round, but a very distinct wet season from November to April, when $90 \%$ of the rain fell (Taylor and Tulloch 1985). Darwin's harbour and coastline are macrotidal, with a mean spring range of $5.5 \mathrm{~m}$ (maximum, $7.8 \mathrm{~m}$ ) and mean neap range of $1.9 \mathrm{~m}$ (Semenuik 1985). The study sites, Ludmilla Creek $\left(12^{\circ} 23^{\prime} \mathrm{S}, 130^{\circ} 51^{\prime} \mathrm{E}\right.$; and Casuarina Coastal Reserve $\left(12^{\circ} 21^{\prime} \mathrm{S}, 130^{\circ} 53^{\prime} \mathrm{E}\right)$, were situated on and around tidal rivers and pools, with c. $100 \%$ canopy cover of tall White Mangrove Avicennia marina and Stilt Mangrove Rhizophora stylosa, and an understory of other shorter mangroves, such as Aegiceras corniculatus and Camptostemon schultzii. These sites supported at least 20 pairs and 8 pairs of Large-billed Gerygones, respectively.

Intensive nest searches were conducted almost every month from 2000 to early 2003 at both sites. Nests of Largebilled Gerygones are large and conspicuous, being suspended from the branch tips of mangroves in the open, with no vegetation underneath them. Consequently, almost all nests were found by systematically searching along the margins of tidal creeks, the preferred habitat of local populations of this species (Noske 1996). Each nest found was given a unique code number on blue (1999-2002), red (2001) or pink (2002) flagging tape placed at least $5 \mathrm{~m}$ from the nest.
Nests were usually monitored every 2-7 days, depending on their status and accessibility. Nest fate was classified as successful or failed or unknown. Nest failure was attributed to one of the following: (1) depredated: with egg or nestling missing prior to the expected date of hatching or fledging, not after high tide or severe weather, often with signs of nest damage; (2) flooded: nests saturated, or dried and stiff, with hood collapsed, usually following a high spring tide; (3) parasitized: nest that successfully produced Little Bronze-cuckoo (Chrysococcyx minutillus) nestling; and 4 ) other causes, which include abandoned nests (nests unattended prior to expected date of hatching or fledging, with cold or cracked eggs or dead nestling) and nests that disappeared, possibly due to drift by tides or storms).

We measured the height of nests less than $2 \mathrm{~m}$ above the muddy ground using a 2-m tape measure during a low tide. Heights of nests between 2 and $5 \mathrm{~m}$ were estimated to the nearest $0.2 \mathrm{~m}$, and heights of over $5 \mathrm{~m}$ were estimated to the nearest $0.5 \mathrm{~m}$. Distance to creek was measured using a tape measure. Nest dimensions were measured only after the nests had been depredated or vacated naturally to minimize disturbance to the breeding birds. For nests that were still in good condition, we measured total nest length, chamber diameter, and entrance width. In addition, we noted the number of old nests within a radius of $10 \mathrm{~m}$ from the active nest. Active nests that were built within $5 \mathrm{~m}$ of a wasp nest were noted. Due to the nature of working in areas that experience large fluctuations in tidal levels, not all measurements could be taken for all nests. This resulted in different sample sizes for some measurements.

\section{Data analysis}

We examined relationships between nest fate and dependent variables of interest using generalized linear modelling (GLM) assuming a binomial error structure $(1=$ success, $0=$ fail) with a logit link function. We fitted these models using the software R 2.13.0 (Ihaka and Gentleman 1996), following the methods of (Crawley 2002). Model simplification using backward-elimination of non-significant explanatory variables and interaction terms was adopted. Terms were systematically removed from the model and only put back in if their removal resulted in a significant loss of model explanatory power, determined by comparing the log-likelihood of the full model to the loglikelihood of the reduced model using the $G^{2}$ test, whose sampling distribution approximates a $\chi^{2}$ distribution with one degree of freedom (Quinn and Keough 2002). The significance of each explanatory variable was similarly determined by comparing the log-likelihood of the full minimal model including the variable of interest to the log-likelihood of the reduced model excluding it. All meaningful interactions (only two-way interactions) were 
included in the saturated model. Because only $42 \%$ of nests had all measurements recorded, if an explanatory variable was found to be non-significant, sample size in the reduced model was increased by including nests that lacked a measurement for that non-significant variable. Residual plots and normal probability plots were used to check for deviations from normality in the final model. To test the prediction that nests located closer to the creek margin and/ or at a lower height are at greater risk of mortality from flooding, we undertook a GLM analysis comparing the characteristics of nests that successfully fledged young (gerygone and/or cuckoo) and those that failed due to flooding. This analysis excluded nests that failed due to predation, abandonment, nestling death or of unknown fate.

To test the combined predictions of the aqua-phobic nest predator hypothesis, that nests located closer to the creek margin and/or at a lower height are at lower risk of mortality from predation, and the potential-prey-site hypothesis, that nests located within a $10 \mathrm{~m}$ radius of old nests are at lower risk of mortality from predation, we undertook a GLM analysis comparing the characteristics of nests that successfully fledged young (gerygone and/or cuckoo) and those that failed due to predation. This analysis included the categorical variable DISPERSION with two categories: (1) clustered (nest located within a $10 \mathrm{~m}$ radius of an old gerygone nest); or (2) solitary (nest located further than $10 \mathrm{~m}$ from an old gerygone nest). As a further test of the nest confusion hypothesis, that nests located closer to an old nest or flood debris are at lower risk of mortality from predation, we undertook a similar GLM analysis that included only nests located within a $10 \mathrm{~m}$ radius of an old nest. These analyses excluded nests that failed due to flooding, abandonment, nestling death or of unknown fate.

\section{Results}

Of 152 known-fate nests, only $21(14 \%)$ were successful in producing one or more fledglings. Of 131 failed nests, 92 (70\%) were depredated and 17 (13\%) flooded by high tides (Table 1). Only 4 nests were located within $5 \mathrm{~m}$ of a

Table 1 Mean (+SD) height of nests of Large-billed Gerygones Gerygone magnirostris, and distance of nest to creek bank (m), according to fate

\begin{tabular}{lll}
\hline Nest fate & Distance to creek $(\mathrm{m})$ & Nest entrance height $(\mathrm{m})$ \\
\hline Flooded & $1.95 \pm 2.10(17)$ & $1.67 \pm 0.59(20)$ \\
Depredated & $3.07 \pm 2.68(92)$ & $1.86 \pm 0.54(105)$ \\
Other causes $^{\mathrm{a}}$ & $2.53 \pm 2.83(22)$ & $1.99 \pm 0.45(27)$ \\
Total failed $_{\text {Total success }}$ & $2.83 \pm 2.58(131)$ & $1.86 \pm 0.54(152)$ \\
\hline
\end{tabular}

a Includes nest abandonment and nest disappearance (due to storm or unknown causes)

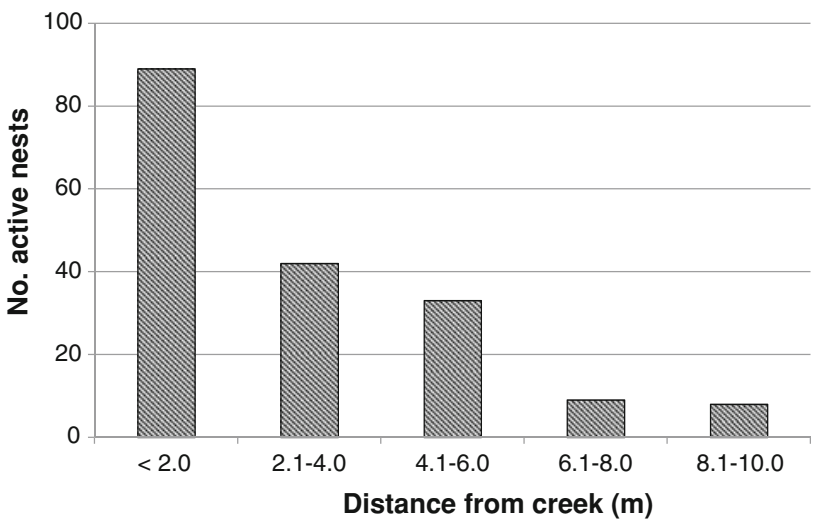

Fig. 1 Distance of nests of Large-billed Gerygones Gerygone magnirostris from the bank of the nearest tidal creek $(n=181)$

wasp nest, whereas 57 nests were situated within $10 \mathrm{~m}$ of an old nest (i.e. clustered). All nests were located within $10 \mathrm{~m}$ of the banks of tidal channels (Fig. 1), the mean distance being $2.9 \mathrm{~m}(\mathrm{SD}=2.8 \mathrm{~m} ; n=187)$. The mean height of the nest entrance from the ground, or (for those nests over water) from the level of the banks of the channel, was $1.9 \mathrm{~m}(\mathrm{SD}=0.7 \mathrm{~m}, n=222)$.

Nest failure through tidal flooding showed no relationship with nest dispersion i.e. whether solitary or close to an old nest $\left(\chi^{2}=0.97, P=0.6\right)$, but decreased significantly with nest height and distance from the tidal channel (Tables 1, 2). Nest failure through predation showed no significant relationship with either distance from the tidal channel $\left(\chi^{2}=2.47, P=0.12\right)$ or nest height $\left(\chi^{2}=2.32\right.$, $P=0.13$ ), but predation was significantly more likely at solitary nests than at clustered nests (Table 2). Among clustered nests, there was no significant effect of distance to old nests (Table 2).

\section{Discussion}

In our study, Large-billed Gerygone nests that were built over or close to tidal creeks, or higher in trees, were no more likely to be predated than those further from the creek or closer to the ground. This finding is inconsistent with the aqua-phobic nest predator hypothesis, which suggests that nests over water should be protected from nest predators that are reluctant to enter or risk falling into water, such as some terrestrial mammals or reptiles. The lack of support for this hypothesis may indicate that the major nest predators of this species are birds, which can easily access nests by flying to them, or mammals and reptiles that are adept swimmers. Indeed, in artificial nests mimicking those of the Large-billed Gerygone, Sato et al. (2010) found that the marks left by 'predators' on plasticine eggs in almost all cases of 'depredation' were from birds. Moreover the 
Table 2 Summary of model terms and statistics for minimal generalised linear models examining the relationship between nest fate (successful $=1$, fail $=0$ ) and dependent variables of interest
No interaction terms were significant

\begin{tabular}{|c|c|c|c|}
\hline Predictor terms & $\chi^{2}$ & $P$ & Effect size \pm SE \\
\hline \multicolumn{4}{|c|}{ Nest survival (successful vs. flooded, $n=20$ successful and 17 flooded nests) } \\
\hline Constant & & & $-4.70 \pm 1.76$ \\
\hline Nest height (m) & 8.95 & 0.003 & $2.09 \pm 0.85$ \\
\hline Distance to creek (m) & 6.91 & 0.009 & $0.37 \pm 0.17$ \\
\hline \multicolumn{4}{|c|}{ Nest survival (successful vs. predation, $n=14$ successful and 51 depredated nests) } \\
\hline Constant & & & $-0.65 \pm 0.37$ \\
\hline Dispersion: solitary & 6.44 & 0.011 & $-1.66 \pm 0.71$ \\
\hline \multicolumn{4}{|c|}{ Nest survival (clustered nests; 11 successful and 21 depredated) } \\
\hline Constant & & & $-0.65 \pm 0.37$ \\
\hline Distance to old nest (m) & 3.01 & 0.08 & \\
\hline Nest height $(\mathrm{m})$ & 2.98 & 0.08 & \\
\hline
\end{tabular}

only predation events witnessed on real nests of this species involved the Black Butcherbird Cracticus quoyi (Mulyani 2004; Sato et al. 2010). The lack of observations or evidence of predation of Large-billed Gerygone nests by terrestrial animals (e.g., mammal faeces, severely damaged nests) casts further doubt on the aqua-phobic nest predator hypothesis, and suggests that factors other than nest predation are involved in nest site selection of this species.

As expected, our data also show that Large-billed Gerygone nests built over or close to tidal creeks, or closer to the ground, were more likely to be flooded than those further from the creek or higher in trees. Inundation from spring tides each fortnight, especially during periods of heavy rainfall, therefore imposes a fitness cost on nesting too close to the ground or tidal channel. Placing the nest over water also presumably poses a risk for young when they leave the nest as there is no foliage underneath the nest which could prevent them from falling into the water should they fail to maintain sufficient altitude on their first flight. However, this risk would be even greater for the fullgrown nestling Little Bronze-cuckoo, which has twice the mass (15 g) of a full-grown Large-billed Gerygone. Therefore, an alternative hypothesis, but one that we do not test, is that building nests over water selects against brood parasitism by the Little Bronze-cuckoo.

Possibly the most significant finding of our study is that active nests situated close to old intact nests suffered less predation than nests that were on their own. This finding is consistent with the potential-prey-site hypothesis as nest predators might give up searching for eggs or nestlings if nearby nests are empty or have no opening. Similarly Galligan and Kleindorfer (2008) argued that in the Yellowrumped Thornbill Acanthiza chrysorrhoa, which builds a cup-shaped "false nest" on top of its real domed nest, conspicuous nests had higher nesting success than less well concealed nests because nest predators choose to conserve energy and time by not examining the nest site more closely. If such 'decoy' nests served to distract visually- oriented nest predators, and induce them to stop searching, then one would expect 'predation' of artificial nests to be low, once such nests were found to be unproductive. Indeed, the 'predation' rate of artificial domed nests with plasticine eggs was lower than the predation rate of natural nests in Large-billed Gerygones (Sato et al. 2010) and Superb Fairy-wrens Malurus cyaneus (Colombelli-Négrel and Kleindorfer 2009), although the difference may have been due to the absence of parental activity (Martin et al. 2000) or other cues at artificial nests, as well as other factors (Colombelli-Négrel and Kleindorfer 2009).

However, a simple alternative explanation for the lower predation rate of nests close to old nests is that the latter, particularly if intact, signify locations that have escaped damage by nest predators. By experimentally adding eggs to real nests from the previous year, showed that nest sites of four ground-nesting species had strong repeatable effects on nest predation rates, with nests in vulnerable sites consistently being quickly depredated. Hass (1998) showed that migratory American Robins moved shorter distances between nests when re-nesting after successfully raising one brood than did robins that re-laid after natural or experimental nesting failure, suggesting that they selected breeding sites based on their previous nesting success. Within a breeding season, pairs of Spotted Antbirds preferred to reuse previously successful nest sites overall, and were more likely to return to these sites for a consecutive nest attempt than they were to previously depredated nest sites, presumably to avoid sites recently discovered by predators (Styrsky 2005).

Building new nests close to old one might also have an anti-predator function for incubating female gerygones, which are susceptible to predation as their enclosed nests offer little chance of escape if the predator is able to reach the entrance. Predators landing on or climbing to old nests might cause sufficient movement of the supporting branch to warn the incubating bird in the active nest of impending danger. 
Although there are many reports in the literature of Large-billed Gerygones nesting near wasp nests, we found few of the latter near gerygone nests at our study sites. Yet there are no published reports of this species nesting close to old nests, and only two of 19 nest records in the Birds Australia Nest Record Scheme were reported as being built $<1.5 \mathrm{~m}$ from old or inactive nests, while in two other cases where two nests were separated by only $50 \mathrm{~cm}$, both nests reputedly contained eggs or young (Higgins and Peter 2002). The elevated frequency of clustered nests in our study area may thus be related to lower abundance of wasps, or to elevated nest predation and/or brood parasitism levels. Nest predation rates during the study period were not exceptionally high $(57 \% ; n=160)$ in this species, whereas an astonishing $41 \%$ of nests were parasitised by the Little Bronze-cuckoo, although many of these nests were also depredated (Mulyani 2004). Brood parasitism rates were also high $(34 \% ; n=138)$ for the coexisting Mangrove Gerygone G. levigaster, whose nests were never observed close to older nests, but this species builds its nests within the foliage of small mangrove shrubs on bare saltflats rather than in the open space over tidal rivers (Mulyani 2004; Noske 2001). Brood parasitism can cause higher reproductive costs than nest predation due to delays in re-nesting resulting from time expended in foster care, and thus may constitute a stronger selection pressure on these species than nest predation in the study area.

Acknowledgments We thank C. Brady, S. Manullang, Y. Widiwardono, R. Funnel, V. Vilar and numerous volunteers who helped in locating nests. We also received substantial help in statistical analysis from K. McGuiness, D. Franklin, and W. Telfer. This study was a part of $\mathrm{PhD}$ research of the second author under the AusAID scholarship scheme.

Open Access This article is distributed under the terms of the Creative Commons Attribution License which permits any use, distribution, and reproduction in any medium, provided the original author(s) and the source are credited.

\section{References}

Beruldsen G (1980) A field guide to nest and eggs of Australian birds. Rigby, Adelaide

Biancucci L, Martin TE (2010) Can selection on nest size from nest predation explain the latitudinal gradient in clutch size? J Anim Ecol 79:1086-1092

Bruce M (2003) Family Eurylaimidae (Broadbills). In: del Hoyo J, Elliott A, Christie DA (eds) Handbook of the birds of the world, vol 8: Broadbills to Tapaculos. Lynx, Barcelona, pp 54-93

Burhans DE, Thompson FR III (1998) Effects of time and nest-site characteristics on concealment of songbird nests. Condor 100:663-672

Campbell AJ, Barnard HG (1917) Birds of the Rockingham Bay District, North Queensland. Emu 17:2-38
Chalfoun AD, Martin TE (2009) Habitat structure mediates predation risk for sedentary prey: experimental tests of alternative hypotheses. J Anim Ecol 78:497-503

Collias NE, Collias EC (1984) Nest building and bird behaviour. Princeton University Press, Princeton

Colombelli-Négrel D, Kleindorfer S (2009) Nest height, nest concealment, and predator type predict nest predation in superb fairy-wrens (Malurus cyaneus). Ecol Res 24:921-928

Cornwall EM (1910) Notes on the Great-billed Heron (Ardea sumatrana). Emu 9:138-141

Crawley MJ (2002) Statistical computing: an introduction to data analysis using S-Plus. Wiley, Chichester

Fitzpatrick JW (2004) Family Tyrannidae (Tyrant-flycatchers). In: del Hoyo J, Elliott A, Christie DA (eds) Handbook of the birds of the world. vol 9 Cotingas to Pipits and Wagtails. Lynx, Barcelona, pp $170-462$

Fontaine JJ, Martin TE (2006) Parent birds assess nest predation risk and adjust their reproductive strategies. Ecol Lett 9:428-434

Franklin DC, Noske RA (2000) The nesting biology of the Brown Honeyeater Lichmera indistincta in the Darwin Region of northern Australia with notes on tidal flooding of nests. Corella 20:38-44

Galligan TH, Kleindorfer S (2008) Support for the nest mimicry hypothesis in Yellow-rumped Thornbills Acanthiza chrysorrhoa. Ibis 150:550-557

Götmark F, Blomqvist D, Johansson OC, Bergqvist J (1995) Nest-site selection: a trade-off between concealment and view of the surroundings. J Avian Biol 26:305-312

Hass CA (1998) Effects of prior nesting success on site fidelity and breeding dispersal: an experimental approach. Auk 115:929-936

Higgins PJ, Peter JM (eds) (2002) Handbook of Australian, New Zealand and Antarctic birds. vol 6 Pardalotes to shrike-thrushes. Oxford University Press, Melbourne

Holway DA (1991) Nest-site selection and the importance of nest concealment in the Black-throated Blue Warbler. Condor 95:83-93

Howlett JS, Stutchbury BJ (1996) Nest concealment and predation in Hooded Warblers: experimental removal of nest cover. Auk 113:1-10

Hudgens BR (1997) Nest predation avoidance by the Blue-billed Malimbe Malimbus nitens (Ploceinae). Ibis 139:692-694

Ihaka R, Gentleman R (1996) R: a language for data analysis and graphics. J Comput Graph Stat 5:299-314

Immelmann K (1961) A contribution to the biology and ethology of Australian honeyeaters (Meliphagidae). Z Ornithol 102:164-207

Johnstone RE (1990) Mangroves and mangrove birds of Western Australia. Western Australian Museum, Perth

Joyce FL (1993) Nesting success of rufous-naped wrens (Campylorhynchus rufinucha) is greater near wasp nests. Behav Ecol Sociobiol 32:71-77

Lack D (1968) Ecological adaptations for breeding in birds. Methuen, London

Le Souëf WHD (1903) Description of birds' eggs from Port Darwin District, Northern Australia. Emu 2:139-159

MacGillivray W (1914) Notes on some North Queensland birds. Emu 13:132-186

MacGillivray W (1918) Ornithologists in North Queensland. Emu $17: 180-212$

Marshall AJ (1933) The Large-billed warbler. Emu 33:81-85

Martin TE (1992) Interaction of nest predation and food limitation in reproductive strategies. Curr Ornithol 9:163-197

Martin TE (1993) Nest predation and nest sites. Bioscience 43: 523-532

Martin TE (1995) Avian life history evolution in relation to nest sites, nest predation and food. Ecol Monogr 65:101-127 
Martin TE, Li P (1992) Life history traits of open- vs cavity-nesting birds. Ecology 73:579-592

Martin TE, Roper JJ (1988) Nest predation and nest site selection in a western population of the hermit thrush. Condor 90:51-57

Martin TE, Scott J, Menge C (2000) Nest predation increases with parental activity: separating nest site and parental activity effects. Proceedings of the Royal Society of London B 267:2287-2293

McGill AR (1970) Australian warblers. Birds Observers Club, Melbourne

Mulyani YA (2004) Reproductive ecology of tropical mangrove-dwelling warblers: the roles of nest predation, brood parasitism and food limitation. PhD thesis, Charles Darwin University, Darwin

Nalwanga D, Lloyd P, Du Plessis MA, Martin TE (2004) The influence of nest-site characteristics on the nesting success of the Karoo Prinia (Prinia maculosa). Ostrich 75:269-274

Noske RA (1996) Abundance, zonation, and foraging ecology of birds in mangroves of Darwin Harbour, Northern Territory. Wildl Res 23:443-474

Noske RA (2001) The breeding biology of the mangrove gerygone, Gerygone laevigaster, in the Darwin region, with notes on brood parasitism by the little bronze-cuckoo, Chrysococcyx minutillus. Emu 101:129-135

Noske RA, Fischer S, Brook BW (2008) Artificial nest predation rates vary among habitats in the Australian monsoon tropics. Ecol Res 23:519-527

Oniki Y (1979) Is nesting success of birds low in the tropics? Biotropica 11:60-69

Quinn GP, Keough MJ (2002) Experimental design and data analysis for biologists. Cambridge University Press, Melbourne

Remeš V (2005) Birds and rodents destroy different nests: a study of blackcap Sylvia atricapilla using the removal of nest concealment. Ibis 147:213-216
Ricklefs RE (1969) An analysis of nesting mortality in birds. Smithson Contrib Zool 9:1-48

Sato NJ, Morimoto G, Noske RA, Ueda K (2010) Nest form, colour, and nesting habitat affect predation rates of Australasian warblers (Gerygone spp.) in tropical mangroves. J Yamashina Inst Ornithol 42:65-78

Semenuik V (1985) Mangrove environments of Port Darwin, Northern Territory: the physical framework and habitats. J R Soc WA 67:81-97

Skutch AF (1966) A breeding bird census and nesting success in Central America. Ibis 108:1-16

Styrsky JN (2005) Influence of predation on nest-site reuse by an open-cup nesting neotropical passerine. Condor 107:133-137

Taylor JA, Tulloch D (1985) Rainfall in the wet-dry tropics: extreme events at Darwin and similarities between years during period, 1870-1983 inclusive. Aust J Ecol 10:281-295

Von Haartman L (1957) Adaptation in hole-nesting birds. Evolution 11:294-347

Weidinger K (2002) Interactive effects of concealment, parental behaviour and predators on the survival of open passerine nests. J Anim Ecol 71:424-437

Wesolowski T, Tomialojć L (2005) Nest sites, nest depredation, and productivity of avian broods in a primeval temperate forest: do the generalisations hold? J Avian Biol 36:361-367

Whitney BM, Pacheco JF, Da Fonseca PSM, Barth RH Jr (1996) The nest and nesting ecology of Acrobatornis fonsecai (Furnariidae), with implications for intrafamilial relationships. Wilson Bull 108:434-448

Wunderle JM Jr, Pollock KH (1985) The Banaquit-wasp nesting association: a random choice model. Ornithol Monogr 36: 595-603 